\title{
Prevalence of refractive error and spectacle coverage in schoolchildren in two urban areas of Chile
}

\author{
Fernando Barria, ${ }^{1}$ Francisco Conte, ${ }^{2}$ Sergio Muñoz, ${ }^{3}$ Janet L. Leasher, ${ }^{4}$ and \\ Juan Carlos Silva ${ }^{5}$
}

Suggested citation

Barria F, Conte F, Muñoz S, Leasher JL, Silva JC. Prevalence of refractive error and spectacle coverage in schoolchildren in two urban areas of Chile. Rev Panam Salud Publica. 2018;42:e61. https://doi. org/10.26633/RPSP.2018.61

ABSTRACT Objective. To assess the impact of efforts to reduce visual impairment by detecting and treating refractive errors (RES) among schoolchildren in two urban areas of Chile.

Methods. In 2013, in the communities of Concepción and La Florida, we conducted a multicenter, multistage-sampling, cross-sectional study employing methods used by the Refractive Error Study in Children (RESC) survey. Best-corrected visual acuity was assessed using pinhole, with and without glasses. The coverage for correcting visual impairment due to refractive error was estimated.

Results. We examined 5412 schoolchildren, in the communities of Concepcion $(n=3049)$ and La Florida $(n=2363)$. Uncorrected visual acuity $(V A)$ of $>0.63$ in at least one eye was found in 4721 children $(87.23 \% ; 95 \%$ confidence interval (CI): $86.58 \%-88.30 \%)$. Of the remaining children, 1017 of them (18.79\%; 95\% CI: 17.78\%-19.80\%) had a VA of < 0.5 in at least one eye. Of the 691 children with uncorrected visual impairment with both eyes open (12.77\%; 95\% CI: 11.9\%-13.64\%), 476 of them (8.76\%; 95\% CI: 8.03\%-9.49\%) achieved normal vision using best possible correction, and with 271 of the 476 (56.93\%) having a normal presenting VA in the better eye.

Conclusions. We found an increased coverage of services for RE-associated visual impairment and an increased percentage of children wearing glasses as compared to values reported for La Florida in an article published in 2000. The National Board of School Aid and Scholarships (JUNAEB) in Chile is achieving better results in its schoolchildren eye care program.

Keywords Refractive errors; students; vision screening; eyeglasses; patient compliance; Chile.

Visual impairment may seriously affect a person's quality of life, both at work and in social environments (1-4). Evidence suggests that visual disorders, e.g., refractive errors (REs), amblyopia,

\footnotetext{
Regional Hospital, Universidad de Concepción, Concepción, Chile.

2 Los Andes Ophthalmological Foundation, Santiago, Chile.

3 Department of Public Health, School of Medicine, University of La Frontera, Temuco, Chile.
}

and strabismus, are found with increasing frequency in children (5). Population-based studies have indicated that uncorrected (with glasses) REs, particularly myopia, are foremost among the

\footnotetext{
4 Nova Southeastern University, Fort Lauderdale, Florida, United States of America.

Pan American Health Organization, Bogotá Colombia. Send correspondence to Juan Carlos Silva at silvajuan@paho.org
}

visual impairments that affect children's learning capacity and development (6-8). Thus, it is of major importance to examine school-age children-a group not typically seeking immediate medical care-in order to detect and correct REs, amblyopia, strabismus, and diseases of the eye (9).

An article published in 2000 reporting on a Refractive Error Study in Children (RESC) survey done in the community of 
La Florida, Chile, indicated that the prevalence of visual impairment associated with REs was $7 \%$ overall (10). Only $24 \%$ of children with uncorrected visual acuity of $\leq 0.5$ (using the Logarithm of the Minimum Angle of Resolution (LogMAR) chart) wore glasses at the time of the exam. Since then, there have been no other studies published in peer-reviewed indexed journals on the prevalence of refractive error in Chilean school-age children. Furthermore, only one known published study addresses the coverage and effectiveness of the Chilean National Board of School Aid and Scholarships (Junta Nacional de Auxilio Escolar y Becas (JUNAEB)) program for detecting and treating REs in children, with a very small sample size of 270 in the community of Concepción, Chile (11). JUNAEB is a national program of the Ministry of Education that performs detection and correction of refractive errors by providing eyeglasses for low-income public school students (12).

The objectives of this study were to: (i) estimate the prevalence of visual impairment in school-age children (5-19 years of age) in the communities of La Florida and Concepción, Chile; (ii) determine the causes of these visual impairments; and (iii) learn the frequency of use of ophthalmic spectacles in this population. Our intent was to assess the current epidemiologic status of visual impairment in school-age children in La Florida and Concepción, and to assess the current response of JUNAEB in the two communities, comparing our results with those of the RESC study on La Florida published in 2000 (10).

\section{MATERIALS AND METHODS}

This investigation was a two-center, multistage-sampling, cross-sectional study of a representative sample of schoolchildren 5-19 years old attending public schools in the urban areas of $\mathrm{La}$ Florida (Santiago metropolitan region) and Concepción (Biobío region). In 2013 the study was approved by the ethics committee of the Faculty of Medicine of the University of Concepción, Concepción, Chile.

The population of school-age children in Concepción consists of 41842 students attending 81 public schools, and in $\mathrm{La}$ Florida it consists of 66849 attending 140 public schools. Our sample under investigation comprised 47 public schools -22 from Concepción and 25 from La Florida-randomly selected from a list of schools provided by each municipality. Three of the originally selected schools refused participation and were replaced according to geographic criteria.

All children from one class per each educational level (comprised of kindergarten, six levels of basic education, and four of secondary school) were examined. The class was randomly selected from each level in the randomly selected schools. The RESC protocol $(10,13-21)$ was modified slightly to use the public school population instead of the census population, and the age group range for subjects was expanded from 10 to 15 years old in the RESC protocol to 5 to 19 years of age in our study.

We compared outcomes between these two communities, and conducted a change analysis in La Florida between these study results and the ones reported on in 2000 (10). Calculation of sample size was based on previously reported prevalence data of REs per age group. We calculated the $95 \%$ confidence interval $(95 \% \mathrm{CI}), 20 \%$ relative error, and effects of specific design per each age group. Based on the 2000 report, we assumed RE prevalence of $5 \%$ for children 5-9 years old, $6.5 \%$ for those 10-13 years old, and 10\% for those 1419 years old. By correcting the sample size by rejection (12\%) and effect of differential design per age group (1.05, 1.25 , and 1.50 , respectively), the sample size required for the study was determined to be 5617 children (5-19 years old). The total sample comprised equal numbers from each community. For the purpose of simplifying the sampling and field work for the study, group numbers were essentially uniform across the three age groups.

Children were examined at their schools from March to December 2013. Examinations were performed by trained ophthalmic assistants, certified in measuring LogMAR visual acuity (VA). A practical exercise was also carried out for all trainees. The VA was tested in a lightson classroom setting with a Tumbling E illiterate ETDRS chart for 13 feet (4 meters) (Good Lite Company, Elgin, Illinois, United States of America).

Survey data were recorded on a previously validated visual examination form $(10,22)$. Children who were absent on the day of the examination were not necessarily followed up on the very next day, in an effort to prevent them from being prepared by wearing their spectacles.

All participants were asked about their spectacle use. VA was measured through a chart of LogMAR optotypes, starting with the upper line $0.1(20 / 200)$ and recording the lowest level at which the student achieved at least four optotypes. The right eye was examined first, followed by the left eye, occluding the contralateral eye in each case. If the child wore glasses, the presenting VA was measured with glasses, followed by measuring uncorrected vision without glasses. If the evaluated vision was $<0.63$, a pinhole was used to estimate best-corrected VA.

For the sensory-motor evaluation, binocular motor function was assessed by means of the cover test at 0.5 and $4 \mathrm{~m}$. Binocular vision was assessed using the Stereo Fly test at $30 \mathrm{~cm}$. (Stereo Optical Co, Inc., Chicago, Illinois, United States). Both external and anterior segment examinations were performed using a penlight, a 20 diopter condensing lens, and a direct ophthalmoscope.

Children with vision $\leq 0.5$ LogMAR (20/40 Snellen) received complete ophthalmological examinations, conducted by an ophthalmologist, in both Concepción and La Florida. Eye examinations were performed with pupil dilation and cycloplegia (cyclopentolate 1\%). Refraction was achieved by refractometry, using an auto refractometer (KR-800 Auto Kerato-Refractometer, Topcon Medical Systems, Inc., Oakland, New Jersey, United States), and confirmed by retinoscopy. REs were defined by subjective refractive correction with: (i) spherical equivalents of less than $<-0.40$ diopters (myopia) or $>+2.00$ diopters (hyperopia); (ii) astigmatism $>0.75$ diopters (10); (iii) improvement of vision with or without pinhole; (iv) and/or no additional organic pathology. To determine the major cause(s) of the visual impairment, i.e., if VA did not improve to $\geq 20 / 32$ with refraction, the anterior segment and lens were examined by slit-lamp biomicroscopy, and the posterior pole was examined by indirect ophthalmoscopy.

Children who wore glasses and those whose uncorrected vision lessened when their glasses were removed were added to the RE group, and their eyeglasses were measured by lensometry. Children not attending ophthalmologic consultations were classified as "possible REs." If strabismus, amblyopia, or other eye 
pathology was detected, the children were directed to the reference hospital. All children with REs were provided eyeglasses at no cost by the JUNAEB program.

Visual impairment refractive error correction coverage was defined as the percentage of visually impairing refractive error that was corrected to $\geq 0.63$ or better in the best eye. Spectacle coverage was defined as the percentage of met need divided by the combined met and unmet refractive error need.

\section{Data management and analysis}

School data forms were reviewed in the field for accuracy and comprehensiveness before computer data entry. Data were captured after each cluster using Microsoft Access software (Microsoft Corp., Redmond, Washington, United States). Consistency among related measurements was checked with a computerized data-cleaning program (Microsoft Corp.). Statistical analyses were performed using version 2009 STATA 11 software (StataCorp LP, College Station, Texas, United States). VA categories comprised vision of $\geq 0.63$ in both eyes or $\geq 0.63$ in the better eye, $0.32-0.5$ in the better eye, $0.12-0.25$ in the better eye, and $\leq 0.1$ in the better eye. Calculation of $95 \%$ CIs was accomplished with adjustment for clustering effects.

Informed consent was obtained for each child. An informed consent template, detailing the objectives of the study, examinations, and tentative dates, was submitted to parents in advance of the study. Parents were encouraged to ask any questions they had before signing the consent.

\section{RESULTS}

\section{Study population}

The sample comprised 5617 students, $5420(96.35 \%)$ of whom were screened during the period of March to December 2013; 8 cases were discarded because of poor records. A total of 3049 (56.33\%) students were from Concepción, and 2363 (43.66 \%) were from La Florida. Of the 47 schools initially selected, 3 of them declined to participate and were thus excluded; they were replaced by 3 schools selected according to geographic proximity. Urban schools from Concepción $(n=22)$ and La Florida $(n=25)$ were evaluated. Of the 5412 students surveyed from these schools, $2824(52.18 \%)$ were girls and 2588 (47.82\%) were boys. The average age of children was 11 years and 6 months, with a standard deviation (SD) of 3 months; sample sizes were uniform across the age groups (Table 1).

\section{Visual acuity}

Normal uncorrected VA $(\geq 0.63)$ in at least one eye was found in $4721(87.44 \%$; 95\% CI: $86.58 \%-88.30 \%$ ) of schoolchildren (Table 2); 1017 (18.79\%; 95\% CI; $17.78 \%-19.80 \%)$ children had a vision $\leq$ 0.5 in at least one eye; and 691 (12.77\%; 95\% CI: $11.9 \%-13.64 \%$ ) were visually impaired with both eyes open. There was a slightly higher prevalence of normal uncorrected VA in children from La Florida (83.16\%; 95\% CI: $81.59 \%-84.61 \%$ ) than in those from Concepción $(79.69 \%$; 95\% CI: $78.23 \%-81.09 \%$ ). Similarly, the pinhole prevalence of $\mathrm{VA} \geq 0.63$ for both eyes in La Florida was $92.42 \%$ (95\% CI: $91.28 \%-$ $93.42 \%$ ) and in Concepción was $88.95 \%$ (95\% CI: $87.78 \%-90.01 \%)$. Visual acuity of $\leq 0.1$ in at least one eye was found in 26 $(0.48 \%)$ children (95\% CI: $0.32 \%-0.70 \%)$ in the two communities combined.

Although $783(14.47 \%)$ children reported using spectacles, only 521 (9.62\%) children were wearing them at the time of the examination. Presenting VA of $\geq$ 0.63 in at least one eye, with or without glasses, was found in 4992 children (92.03\%); $420(7.76 \%)$ children remained visually impaired, including 2 (0.04\%) who presented with visual acuity $\leq 0.1$ (Table 2).

A total of $4896(90.46 \%)$ children achieved normal vision in at least one eye using best possible correction with pinhole, while $516(9.54 \%)$ had a vision $\leq 0.5$ in at least one eye. Of the 691 children with uncorrected visual impairment in the better eye $(12.77 \%), 215$ of them $(31.11 \%)$ remained visually impaired even with the best possible correction. Conversely, 476 of the 691 children $(68.89 \%)$ had normal vision while using best correction with pinhole. Of this latter group, 271 (56.93\%) had a normal presenting VA in the better eye. In Concepción, out of 456 children $(14.96 \%)$ with uncorrected visual impairment with both eyes open, 303 children $(9.94 \%)$ achieved normal vision using best possible correction with pinhole, and 182 (5.97\%) had normal presenting visual acuity in the better eye.
TABLE 1. Number of schoolchildren by age, sex, and community in study of prevalence of refractive error and spectacle coverage in schoolchildren in two urban areas of Chile, 2013

\begin{tabular}{lrrrrrrrr}
\hline \multirow{2}{*}{$\begin{array}{l}\text { Age } \\
\text { (yr) }\end{array}$} & \multicolumn{3}{c}{ Concepción } & & \multicolumn{3}{c}{ La Florida } \\
\cline { 2 - 5 } \cline { 7 - 9 } & Female & Male & Total & & Female & Male & Total \\
\hline 5 & 7 & 6 & 13 & & 0 & 0 & 0 \\
6 & 108 & 102 & 210 & & 66 & 66 & 132 \\
7 & 126 & 129 & 255 & & 84 & 99 & 183 \\
8 & 135 & 122 & 257 & & 117 & 102 & 219 \\
9 & 130 & 121 & 251 & & 105 & 96 & 201 \\
10 & 162 & 125 & 287 & & 123 & 96 & 219 \\
11 & 146 & 164 & 310 & & 107 & 89 & 196 \\
12 & 149 & 142 & 291 & & 96 & 67 & 163 \\
13 & 131 & 118 & 249 & & 82 & 74 & 156 \\
14 & 114 & 114 & 228 & & 82 & 92 & 174 \\
15 & 118 & 103 & 221 & & 92 & 105 & 197 \\
16 & 118 & 87 & 205 & & 121 & 109 & 230 \\
17 & 105 & 90 & 195 & & 98 & 93 & 191 \\
18 & 37 & 25 & 62 & & 46 & 39 & 85 \\
19 & 13 & 2 & 15 & 6 & 11 & 17 \\
Total & 1599 & 1450 & 3049 & & 1225 & 1138 & 2363 \\
\hline
\end{tabular}

Source: Prepared by the authors from the study results.

At the time of the study, $60 \%$ of children with visually impairing RE presented with normal corrected visual acuity. In La Florida, of 235 (9.96\%) children with uncorrected visual impairment in the best eye, 173 (7.26\%) achieved normal vision using best possible correction with pinhole, and 89 (3.73\%) had normal presenting visual acuity in the better eye. At the time of the study, 51.1\% of children with visually impairing RE presented with normal corrected visual acuity (Table 2).

\section{Spectacle wear}

At the time of examination, 328 $(10.76 \%)$ of the 3049 Concepción children were wearing spectacles, as were $193(8.17 \%)$ of the 2363 La Florida children (Table 3$)$. Of the children $(n=1017)$ with an uncorrected visual impairment of $\leq 0.50$ in one or both eyes, $144(14.2 \%)$ wore glasses, as did $73(10.6 \%)$ of the 691 with visual impairment in both eyes.

The chief self-reported causes for not wearing glasses among the 262 children who had been prescribed, but who were not wearing, spectacles included "I don't like to wear them" ( $n=139$ cases, $53.05 \%$ ) and "are broken" ( $\mathrm{n}=70$ cases, 26.72\%) (Table 4). "Occasional wear" was more frequent in older children (> 14 years) compared to younger $(<14$ years) children $(11.36 \%$ versus $6.38 \%$, respectively), 


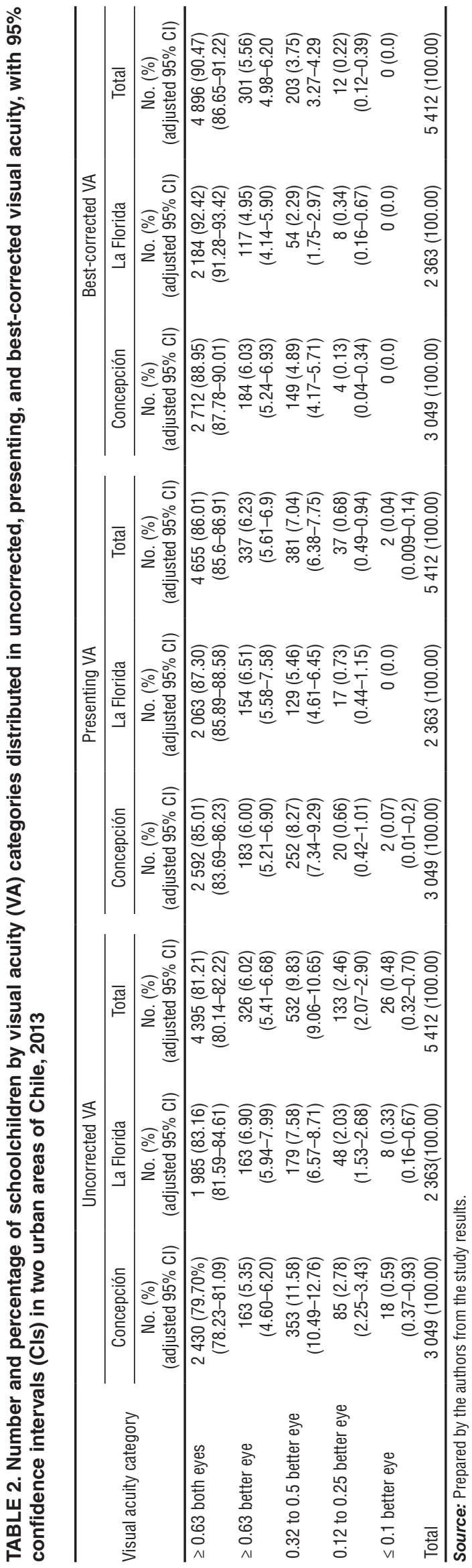

while "lost glasses" was more common in children aged 5-9 years compared to older children $(12.77 \%$ versus $4.55 \%$, respectively).

\section{Referrals to eye care services}

Of 5412 children surveyed and studied, $752(13.9 \%)$ were referred to ophthalmologic examination for having visual impairment in one or both eyes. Of these 752 referred children, $660(87.76 \%)$ were examined, while $92(12.23 \%)$ did not attend the examination.

If an uncorrected VA improved to normal with existing glasses or pinhole, the cause of impairment was considered to be refractive error (RE), even in the presence of other pathologies. RE was also considered as being the primary cause when VA did not improve to normal, provided the refraction was myopic/hyperopic and no other pathology was detected. RE was found in $534(71.01 \%)$ of referred children, and was considered to be the major cause of visual impairment. Of the 752 referred children, $300(56.2 \%)$ were girls. Causes of visual impairment included amblyopia ( $\mathrm{n}=185,3.42 \%$ ), which was more frequent $(4.36 \%)$ in younger (5-9 years) children compared with older (> 14 years) $(2.53 \%)$ children; strabismus ( $\mathrm{n}=115,2.12 \%)$; and undetermined etiology $(\mathrm{n}=32,3.4 \%)$ (Table 5). An additional $4(0.4 \%)$ children presented with corneal opacities associated with infection $(\mathrm{n}=3,0.06 \%)$ and trauma $(\mathrm{n}=1,0.02 \%) ; 2$ other children $(0.04 \%)$ presented with unilateral ocular trauma (both with vision $<0.1$ ); and 1 child $(0.02 \%)$ had phthisis bulbi.

\section{DISCUSSION}

This report delineates the epidemiologic conditions of schoolchildren in La Florida and Concepción, Chile, in 2013, and the national eye care program responses.

Our 2013 reported prevalence of uncorrected visual impairment in schoolchildren aged 5-19 years in Concepción and La Florida, which was 16.82\% (95\% CI: $15.31 \%-18.33 \%$ ) in at least one eye, was not was not significantly higher than the prevalence reported for La Florida in the year 2000, which was 15.84\% (95\% CI: $14.85 \%-16.83 \%)$. Similarly, uncorrected visual impairment in the best eye in the current La Florida study, of $9.94 \%$ (95\% CI: $8.75 \%-11.13 \%)$, was not statistically 
TABLE 3. Number and percent of schoolchildren wearing spectacles in Concepción and La Florida, Chile, 2013 ${ }^{\mathrm{a}}$

\begin{tabular}{|c|c|c|c|c|c|c|}
\hline \multirow{2}{*}{ Visual acuity category } & \multicolumn{2}{|c|}{ Concepción } & \multicolumn{2}{|c|}{ La Florida } & \multicolumn{2}{|c|}{ Total } \\
\hline & No. & $\%$ & No. & $\%$ & No. & $\%$ \\
\hline$\geq 0.63$ both eyes & 226 & 7.41 & 151 & 6.39 & 377 & 6.97 \\
\hline$\geq 0.63$ better eye & 47 & 1.54 & 24 & 1.02 & 71 & 1.31 \\
\hline 0.32 to 0.5 better eye & 53 & 1.74 & 16 & 0.68 & 69 & 1.27 \\
\hline 0.12 to 0.25 better eye & 2 & 0.07 & 2 & 0.08 & 4 & 0.00 \\
\hline$\leq 0.1$ better eye & 0 & 0.00 & 0 & 0.00 & 0 & 0.00 \\
\hline Total/Overall & 328 & 10.76 & 193 & 8.17 & 521 & 9.63 \\
\hline
\end{tabular}

Source: Prepared by the authors from the study results.

aThe values in the table refer to the number and percent of those within each uncorrected visual acuity category wearing spectacles.

TABLE 4. Number and percentage of children's reasons for not wearing spectacles among those students who reported using spectacles but were not wearing them at the examination in Concepción and La Florida, Chile, in 2013

\begin{tabular}{lrr}
\hline Reason & No. & \multicolumn{1}{c}{$\%$} \\
\hline Don't like glasses & 139 & 53.05 \\
Glasses broken & 70 & 26.72 \\
Occasional use & 28 & 10.69 \\
Lost glasses & 16 & 6.11 \\
Did not get the glasses & 5 & 1.91 \\
Bad visual acuity with glasses & 4 & 1.53 \\
Total & 262 & 100.00 \\
\hline
\end{tabular}

Source: Prepared by the authors from the study results.

different from that reported in the 2000 article on La Florida, which was $8.57 \%$ (95\% CI: $7.81 \%-9.33 \%$ ). Since the study populations in both Concepción and La Florida comprise students in urban public schools, there is no apparent explanation as to why uncorrected visual impairment is higher in Concepción.

Taken together, the prevalence of uncorrected visual impairment in the best eye in La Florida and Concepción was $12.77 \%$. That figure was lower than those reported for China, of 27\% (21) and $22.3 \%$ (17), and for Malaysia, of $17.1 \%$ (20), but higher than those reported for New Delhi (6.4\%) (18) and for rural India (2.74\%) (17). In a 2008 study of schoolchildren in the city of São Paulo, Brazil, uncorrected visual impairment in the best eye was found to be $4.82 \%$ (22). Differences in prevalence among Concepción, La Florida, and São Paulo suggest the influence of other causes besides urbanization, such as genetic, ethnic, or environmental ones.

There was no statistically significant difference in the prevalence of uncorrected normal vision between the value reported in the 2000 article on La Florida
(10) and those of the 2013 studies in Concepción and La Florida. These results are in contrast to ones indicating an increasing prevalence of unaided VA impairment due to myopia, as documented in findings in the China studies were attributed to a higher incidence of myopia in the younger generation (23). In the United States, that incidence has also increased in the past 30 years (24). Higher levels of schooling and education are associated with a higher incidence of myopia (25).

In La Florida, out of the 173 children (7.26\%) who achieved normal best corrected vision, $51 \%$ of them were corrected with spectacles that the JUNAEB program had provided. This figure is in contrast to the $25 \%$ reported in the study published in 2000 about the same community, and the $49 \%$ in the 2008 São Paulo study (22). These results in La Florida in 2013 are not only successful when compared to the study published in the year 2000, but also similar to or better than urban studies in southern China (16); New Delhi, India (18); and Malaysia (20). The results in Concepción in 2013 are even better than those in La Florida in the same year, with $60 \%$ being corrected with spectacles from the national program. In this study in 2013, we found that the percentage of children wearing glasses was higher in Concepción $(10.76 \%)$ and in La Florida $(8.17 \%)$ than the $4.65 \%$ reported for La Florida in the study published in 2000 (10). This improvement in results is suggestive of increased awareness and higher coverage and effectiveness of the JUNAEB eye care program for schoolchildren, and more compliance in wearing spectacles.

According to personal communications between the authors and JUNAEB management staff and ophthalmologists, there are three factors that could explain studies conducted in China (21). The these successful results: 1) having a mandatory long-term schoolchildren health program supported by a law; 2) integration of eye care as part of the schoolchildren health program; and 3) the program's compliance with norms and guidelines with precise criteria for detection, referrals, prescriptions, and treatment.

Other worldwide researchers also suggest that school-based vision screening carried out by teachers and other ancillary personnel may be an effective means of detecting affected children and of improving their visual function with spectacles (26). The study done in Concepción, Chile, in 2010 (11) indicated the effectiveness of providing free spectacles to students and utilizing trained personnel for VA testing to detect visual impairment and REs, in order to improve compliance and reduce unnecessary referrals. Nonetheless, 115 of referred children $(15.29 \%)$ in this study in 2013 were normal, and only 5 children $(0.09 \%)$ were uncooperative at the time of the examination, fewer than reported in similar studies $(10,13,16)$.

The compliance with spectacle wear was also higher, $66.54 \%$ (521 of 783) in 2013 , than the $58 \%$ reported in Concepción in 2010 (11). Such a result is possibly attributable to recent changes in policies. Teachers now use a template to follow up on the compliance of students who receive eyeglass prescriptions, and the frames have a more acceptable appearance for children.

In this study in 2013, $43.07 \%$ of children in Concepción and La Florida still presented with refractive visual impairment but without spectacle correction provided by the JUNAEB program. This was perhaps due to suboptimal compliance vis-à-vis utilization of glasses, as described in a 2010 report on a study in Sydney, Australia (27). An additional factor for presenting refractive visual impairment is a low frequency of vision assessments among schoolchildren aged 5-19 years who develop undetected myopia, as reported by the Collaborative Longitudinal Evaluation of Ethnicity and Refractive Error Study in the United States (28). Such age-group children typically require frequent rescreening, especially those initially found to require refractive correction (29). In our 2013 study, 68 children $(1.26 \%)$ were in the first grade and may not have been tested and prescribed glasses by the JUNAEB 
TABLE 5. Number and percentage of causes of uncorrected visual acuity (VA) 0.50 or worse among schoolchildren in Concepción and La Florida, Chile, in 2013

\begin{tabular}{lcc}
\hline Cause & $\begin{array}{c}\text { Children with VA } \leq 0.50 \\
\text { (in one or both eyes) }\end{array}$ & $\begin{array}{c}\text { Percent prevalence in the population } \\
(\mathrm{n}=5 \text { 412) }\end{array}$ \\
\hline Refractive error one or both eyes) & ${ }^{\mathrm{b}}$ \\
Amblyopia & $794(85.50 \%)$ & $14.70 \%$ \\
Strabismus & $185(19.90 \%)$ & $3.42 \%$ \\
Did not come to exam & $115(12.40 \%)$ & $2.12 \%$ \\
Unexplained cause & $92(9.90 \%)$ & $1.70 \%$ \\
Corneal opacity & $32(3.40 \%)$ & $0.59 \%$ \\
Retinal disorders & $4(0.40 \%)$ & $0.07 \%$ \\
Keratoconus & $4(0.40 \%)$ & $0.07 \%$ \\
Optic atrophy & $3(0.30 \%)$ & $0.06 \%$ \\
Ocular trauma & $3(0.30 \%)$ & $0.06 \%$ \\
Any cause & $2(0.20 \%)$ & $0.04 \%$ \\
\hline
\end{tabular}

Source: Prepared by the authors from the study results.

${ }^{a}$ Children with visual acuity 0.50 or worse in one or both eyes may represent two different causes of reduced vision. Thus, the total for all causes exceeds the any-cause number.

${ }^{\text {b}}$ Refractive error was assigned as the cause of reduced vision in one or both eyes in 534 children with subjective refraction by the ophthalmologists at the referral center, and in 260 children at the time of the visual acuity exam at the school with uncorrected visual acuity $\leq 0.50$ presenting normal vision using spectacles.

program before the study. Another important associated factor for not wearing glasses is that of having visual impairment in just one eye.

Further qualitative research is needed to assess the key determinants for increasing effectiveness of the eye care programs among schoolchildren, as well as to determine the impact that correcting refractive errors caused by visual impairment has on children's school performance and quality of life (30).

Two children $(0.04 \%)$ in our study presented functional low vision, which is an uncorrectable or untreatable visual impairment (31). These two children had been integrated into the school, and wore special optical aids provided by JUNAEB, indicating the educational system's inclusiveness of the two children.

This study presents evidence of a national program that is increasingly meeting the visual impairment needs of schoolchildren. As a result of policy changes, there is a higher percentage of children using corrective devices (compliance with spectacle use). Several strategies to increase compliance and make the JUNAEB program even more effective are: (i) adhering to national and international standards on school health; (ii) developing, implementing, and monitoring long-term policies, thus providing sustainability and ongoing improvement in the effectiveness of the program; and (iii) integrating children with visual disabilities into regular schools.

There were some limitations to this study. Since the sample size was calculated to be representative of the entire group of schoolchildren, and not calculated to be representative of each age group, an equal sample of about 1800 children was drawn from each of the three age groups, and no comparisons on prevalence of visual impairment were made among the three age groups. The sampling in this study was school based, whereas the baseline study in Chile published in 2000 was population based. Despite the fact that schooling is available in $99 \%$ of Chile, school-based sampling would underrepresent the scope of visual disability and blindness.

Acknowledgments. The authors thank all the following for their support: the Junta Nacional de Auxilio Escolar y Becas (JUNAEB) in Chile, the professional staff who participated in the study, the Ministry of Health of Chile, and the Pan American Health Organization.

Funding. This study was financially supported by Chile's Fondo Nacional de Investigación y Desarrollo en Salud (FONIS) grant number SA12I2223 of December 2012.

Conflicts of Interest. None declared.

Disclaimer. Authors hold sole responsibility for the views expressed in the manuscript, which may not necessarily reflect the opinion or policy of the RPSP/ PAJPH or PAHO.

\section{REFERENCES}

1. Zaba J. Children's vision care in the $21^{\text {st }}$ century \& its impact on education, literacy, social issues, \& the workplace: a call to action. J Behav Optom. 2011;22(2):39-41.

2. Pradhan KB. Impact of uncorrected vision on productivity-a study in an industrial setting a pair of spectacles. J Multidiscip Res Healthc. 2015;1(2):119-31.

3. Cochrane G, Lamoureux E, Keeffe J. Defining the content for a new quality of life questionnaire for students with low vision (The impact of vision impairment on children: IVI_C). Ophthal Epidemiol. 2008;15(2)114-20.

4. Resnikoff S, Pascolini D, Mariotti SP, Pokharel GP. Global magnitude of visual impairment caused by uncorrected refractive errors in 2004. Bull World Health Organ. 2008;86(1):63-70.
5. Tarczy-Hornoch K, Varma R, Cotter SA, McKean-Cowdin R, Lin JH, Borchert MS, et al. Risk factors for decreased visual acuity in preschool children. Ophthalmol. 2011 Nov;118(11):2262-73.

6. Glewwe P, Park A, Zhao. Visualizing development: eyeglasses and academic performance in rural primary schools in China. St. Paul: Center for International Food and Agricultural Policy, University of Minnesota, Department of Applied Economics; 2012. Available from http:// ageconsearch.umn.edu/bitstream / 120032/2/WP12-2.pdf Accessed on 15 March 2017.

7. Krumholtz I. Results from a pediatric vision screening and its ability to predict academic performance. Optom. 2000;71(7): 426-30.
8. Cass HD, Sonksen PM, McConachie HR. Developmental setback in severe visual impairment. Arch Dis Child. 1994;70: 192-6.

9. American Academy of Ophthalmology. Pediatric ophthalmology/strabismus summary benchmarks - 2016. Available from: https://www.aao.org/summarybenchmark-detail/pediatric-ophthalmology-strabismus-summary-benchma Accessed on 15 March 2017.

10. Maul E, Barroso S, Muñoz SR, Sperduto RD, Ellwein LB. Refractive error study in children: results from La Florida, Chile. Am J Ophthalmol. 2000 Apr 1;129(4): 445-54.

11. Barria von Bischhoffshausen F, Muñoz B, Riquelme A, Ormeño MJ, Silva JC. Spectacle-wear compliance in school 
children in Concepción, Chile. Ophthal Epidem. 2014;21(6):362-9.

12. Junta Nacional de Auxilio Escolar y Becas, Ministerio de Educación, Gobierno de Chile. JUNAEB, Ministerio de Educación, Gobierno de Chile. Available from https: / / www.junaeb.cl/ Accessed on 15 March 2017.

13. Negrel AD, Maul E, Pokharel GP, Zhao J, Ellwein LB. Refractive error study in children: sampling and measurement methods for a multi-country survey. Am J Ophthalmol. 2000;129(4):421-6.

14. Pokharel GP, Negrel AD, SR Muñoz, Ellwein LB. Refractive error study in children: results from Mechi Zone, Nepal. Am J Ophthalmol. 2000;129(4):436-44.

15. Zhao J, Pan X, Sui R, Muñoz SR, Sperduto $\mathrm{RD}$, Ellwein LB. Refractive error study in children: results from Shunyi District, China. Am J Ophthalmol. 2000;129(4):427-35.

16. He M, Zeng J, Liu Y, Pokharel GP Ellwein LB. Refractive error and visual impairment in urban children in southern China. Invest Ophthalmol Vis Sci. 2004;45(3):793-9.

17. Dandona R, Dandona L, Srinivas M, Sahare P, Narsaiah S, Muñoz SR, et al. Refractive error in children in a rural population in India. Invest Ophthalmol Vis Sci. 2002;43(3):615-22.

18. Murthy GVC, Gupta SK, Ellwein L, Muñoz SR, Pokharel GP, Sanga L, et al. Refractive error in children in an urban population in New Delhi. Invest Ophthalmol Vis Sci. 2002;43(3):623-31.

19. Naidoo KS, Raghunandan A, Mashige KP, Govender P, Holden BA, Pokharel GP, et al.
Refractive error and visual impairment in African children in South Africa. Invest Ophthalmol Vis Sci. 2003;44(9):3764-70.

20. Goh PP, Abqariyah Y, Pokharel GP, Ellwein LB. Refractive error and visual impairment in school-age children in Gombak District, Malaysia. Ophthalmol. 2005;112(4): 678-85.

21. He M, Huang W, Zheng Y, Huang L, Ellwein LB. Refractive error and visual impairment in school children in rural southern China. Ophthalmol. 2007;114(2): 374-82.

22. Salomão S, Cinoto RW, Berezovsky A, Mendieta L, Nakanami C, Lipener C, et al. Prevalence and causes of visual impairment in low-middle income school children in São Paulo, Brazil. Invest Ophthalmol Vis Sci. 2008;49(10):4308-13.

23. Lin Z, Gao TY, Vasudevan B, Jhanji V, Ciuffreda KJ, Zhang P, et al. Generational difference of refractive error and risk factors in the Handan Offspring Myopia Study. Invest Ophthalmol Vis Sci. 2014; 55(9):5711-7.

24. Vitale S, Sperduto RD, Ferris FL 3rd. Increased prevalence of myopia in the United States between 1971-1972 and 1999-2004. Arch Ophthalmol. 2009;127(12): 1632-9.

25. Mirshahi A, Ponto K, Hoehn R, Zwiener I, Zeller T, Lackner K, et al. Myopia and level of education: results from the Gutenberg Health Study. Ophthalmol. 2014;121(10): 2047-52.

26. Sharma A, Congdon N, Patel M, Gilbert C. School-based approaches to the correction of refractive error in children, Surv Ophthalmol 2012;57(3):272-83.

27. Leone JF, Mitchell P, Morgan IG, Kifley A, Rose KA. Use of visual acuity to screen for significant REs in adolescents: Is it reliable? Arch Ophthalmol. 2010;128(7): 894-9.

28. Kleinstein RN, Sinnott LT, Jones-Jordan LA, Sims J, Zadnik K; Collaborative Longitudinal Evaluation of Ethnicity and Refractive Error Study Group. New cases of myopia in children. Arch Ophthalmol. 2012;130(10)1274-9.

29. Zhao J, Mao J, Luo R, Li F, Munoz SR, Ellwein LB The progression of refractive error in school-age children: Shunyi district, China. Am J Ophthalmol. 2002;134(5): 735-43.

30. Schneider J, Leeder SR, Gopinath B, Wang JJ, Mitchell P. Frequency, course, and impact of correctable visual impairment (uncorrected refractive error). Surv Ophthalmol. 2010;55(6):539-60.

31. Limburg H, Espinoza R, Lansingh VC, Silva JC. Functional low vision in adults from Latin America: findings from population-based surveys in 15 countries. Rev Panam Salud Publica. 2015;37(6): $371-8$.

Manuscript received on 17 May 2017. Revised version accepted for publication on 17 August 2017
RESUMEN

Prevalencia de los errores refractivos $y$ cobertura del uso de lentes en escolares de dos zonas urbanas de Chile

Palabras clave
Objetivo. Evaluar la repercusión de las medidas para reducir la deficiencia visual mediante la detección y el tratamiento de los errores refractivos en escolares de dos zonas urbanas de Chile.

Métodos. En el 2013, en las comunas de Concepción y La Florida, realizamos un estudio transversal multicéntrico, con muestreo en varias etapas, con los métodos del estudio de error refractivo en niños conocido como RESC por su sigla en inglés. La agudeza visual mejor corregida se evaluó con un agujero estenopeico, con y sin lentes. Se calculó la cobertura de la corrección de las deficiencias visuales secundarias a errores de refracción.

Resultados. Examinamos a 5412 escolares en las comunidades de Concepción ( $n=3049)$ y La Florida $(n=2363)$. Se encontró una agudeza visual sin corrección $>0,63$ cuando menos en un ojo en 4721 niños $(87,23 \%$; intervalo de confianza de 95\% [IC]: 86,58\%-88,30\%). De los niños restantes, 1017 (18,79\%; IC de 95\%: $17,78 \%-19,80 \%$ ) tenían una agudeza visual $<0,5$ cuando menos en un ojo. De los 691 niños con deficiencia visual sin corrección con ambos ojos abiertos (12,77\%; IC de 95\%: 11,9\%-13,64\%), 476 niños lograron la visión normal con la mejor corrección posible (8,76\%; IC de 95\%: 8,03\%-9,49\%); 271 de estos 476 (56,93\%) tenían agudeza visual normal en el ojo mejor al inicio.

Conclusiones. Encontramos una mayor cobertura de los servicios para la deficiencia visual secundaria a errores refractivos y un mayor porcentaje de niños que usaban lentes en comparación con los valores notificados para La Florida en un artículo publicado en el 2000. La Junta Nacional de Auxilio Escolar y Becas (JUNAEB) de Chile está logrando mejores resultados en su programa de atención oftalmológica para los escolares.

Errores de refracción; estudiantes; selección visual; anteojos; cooperación del paciente; Chile. 
RESUMO Objetivo. Avaliar o impacto dos esforços para reduzir a baixa visão ao detectar e tratar erros de refração em escolares em duas áreas urbanas do Chile.

Métodos. Foi realizado um estudo transversal multicêntrico com amostragem em múltiplos estágios, com a aplicação da metodologia do Estudo de erros de refração em

Prevalência de erros de refração e cobertura de óculos em escolares em duas áreas urbanas do Chile

Palavras-chave crianças (RESC), nas comunidades de Concepción e La Florida em 2013. A melhor acuidade visual corrigida foi avaliada com fenda estenopeica, com e sem óculos. Foi estimada a cobertura para corrigir a visão por erros de refração.

Resultados. Foram examinados 5.412 escolares nas comunidades de Concepción ( $\mathrm{n}=3.049)$ e La Florida $(\mathrm{n}=2.363)$. Acuidade visual $(\mathrm{AV})$ não corrigida $>0,63$ em pelo menos um olho foi observada em 4.721 crianças $(87,23 \%$; intervalo de confiança de $95 \%$ [IC]: 86,58\%-88,30\%). Do restante, 1.017 crianças (18,79\%; IC de 95\%: 17,78\%-19,80\%) apresentaram AV <0,5 em pelo menos um olho. Das 691 crianças com baixa visão não corrigida medida com ambos os olhos abertos (12,77\%; IC de 95\%: 11,9\%-13,64\%), 476 (8,76\%; IC de 95\%: 8,03\%-9,49\%) atingiram visão normal com a melhor correção visual possível e, destas, 271 (56,93\%) tiveram AV normal no melhor olho.

Conclusões. Foi observado um aumento da cobertura dos serviços para baixa visão associada a erros de refração e um aumento na porcentagem de crianças usando óculos quando comparado aos dados informados na comunidade La Florida em artigo publicado em 2000. A comissão nacional chilena de auxílio escolar e bolsas de estudos (JUNAEB) está conseguindo obter resultados melhores com o programa de atenção à saúde ocular de escolares. 